\title{
Maternal-Fetal Interactions Affect Growth of Human Immunodeficiency Virus Type 1 Transgenic Mice
}

\author{
ROBERTA R. FRANKS, ${ }^{1}$ PATRICIO E. RAY, CECELIA C. BABBOTT, JOSEPH L. BRYANT, \\ ABNER L. NOTKINS, THOMAS J. SANTORO ${ }^{2}$ AND PAUL E. KLOTMAN ${ }^{3}$ \\ Laboratory of Oral Medicine [R.R.F., C.C.B., A.L.N.], Animal Care Unit [J.L.B.], Laboratory of \\ Developmental Biology [T.J.S., P.E.K.], National Institute of Dental Research, National Institutes of \\ Health, Bethesda, Maryland 20892; and Children's Research Institute [P.E.R.], Children's Hospital \\ National Medical Center, Washington, DC 20010
} \begin{abstract}
ABS
Infants vertically infected with human immunodeficiency vi-
rus type 1 (HIV-1) often manifest profoundly deficient growth with failure to thrive. The pathologic mechanisms that produce growth failure associated with pediatric HIV infection are not clear. Transgenic mice homozygous for a gag/pol deletion mutant of the infectious provirus pNL4-3 have been found to manifest a similar growth failure pattern. To explore the influence of HIV-1 on fetal growth and maternal-fetal interactions, we examined intrauterine growth of transgenic and nontransgenic mice and evaluated the consequence of embryo transfer into normal and heterozygous transgenic mothers. Mice homozygous for the HIV transgene had normal intrauterine and birth weights but uniformly displayed severe growth retardation postnatally. Transgene expression was prominent in transgenic fetuses and their placentas and in uteri of transgenic mothers, as determined by Northern analysis. Although embryo transfer did not affect intrauterine growth, the pregnancy rate in transgenic mothers was markedly lower than in nontransgenic controls. In both fetal and neonatal tissues, transgene expression was significantly greater in
\end{abstract}

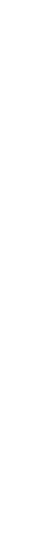


In addition, children vertically infected with HIV frequently come from deprived social environments. These environments are associated with a high rate of maternal substance abuse, inadequate prenatal care, preterm delivery, and poor nutritional status, all of which are correlated with growth delay in utero and make it difficult to ascertain the precise etiology of observed growth deficiencies.

To address the issues of fetal and neonatal growth independent of psychosocial and cofactor influence, we have used a transgenic mouse model. The line $\mathrm{Tg} 26$ was previously generated (31) by introducing as a transgene into mice a deletion mutant of the infectious HIV-1 provirus pNLA-3. This 7.4-kb construct lacks $3 \mathrm{~kb}$ of sequence overlapping the gag and pol genes but encodes the env (evelope) gene and the accessory genes tat, rev, nef, vif, vpr, and vpu under the control of the HIV-1 LTR. Recently, we described a syndrome of growth failure, cachexia, and high mortality in mice homozygous for the defective proviral genome (32). The objectives of our studies were to determine the time of onset of growth failure in HIV transgenic mice and to examine the influence of the transgenic mother on the growth of both fetus and neonate. Fetal growth was determined in transgenic and nontransgenic mothers and neonatal growth was assessed with both natural and foster mothers. We also examined viral gene expression during pregnancy and in newborn transgenic mice and determined the earliest onset of growth failure in homozygous HIV-transgenic mice.

\section{METHODS}

Transgenic mice. The generation of the transgenic mouse line $\mathrm{Tg} 26$ has been described previously (31). The transgene, derived from the molecular clone pNL4-3, contained $7.4 \mathrm{~kb}$ of the HIV-1 proviral genome deleted in the $g a g$ and pol genes under the control of the viral LTR. Descriptions of the nephropathy that develops in heterozygous transgenics have been published previously $(31,33)$. Transgenic mice also develop hyperproliferative skin disorders manifested as benign papillomas in heterozygous mice and diffuse epidermal hyperplasia in homozygotes (34). In addition to the skin lesions, homozygous mice develop a syndrome of growth failure and cachexia with lymphoproliferation, preservation of $\mathrm{CD}^{+}$and $\mathrm{CD} 8^{+}$ T-lymphocyte number, thymic atrophy, and early death (32). In our study, heterozygous transgenic mice were cross-bred to produce litters with homozygous transgenic, heterozygous transgenic, and nontransgenic mice. Genotypes were determined by Southern blot analysis (below). Care of mice was in accordance with National Institutes of Health guidelines.

Southern blot analysis. Ten $\mu \mathrm{g}$ of tail DNA were digested with $E c o$ RI, electrophoresed through $0.8 \%$ agarose gels, transferred to nylon membranes, and fixed by UV cross-linking (Stratagene, La Jolla, CA). DNA was hybridized with a cDNA encoding the HIV-1 nef gene (35) radioactively labeled using $\left[{ }^{32} \mathrm{P}\right] \mathrm{dCTP}$ (New England Nuclear/Du Pont, Boston, MA) by the random primer method (Boehringer-Mannheim, Indianapolis, IN). Hybridization was performed at $65^{\circ} \mathrm{C}$ in $5 \times \mathrm{SCC}$ ( $1 \times \mathrm{SSC}$ is $0.15 \mathrm{M} \mathrm{NaCl}, 0.15 \mathrm{M}$ sodium citrate), $0.5 \% \mathrm{SDS}$, $5 \times$ Denhardt's solution $(1 \times$ Denhardt's is $0.2 \%$ Ficoll, $0.2 \%$ polyvinylpyrrolidone, $0.2 \%$ BSA-Pentax V), with $100 \mathrm{mg} / \mathrm{mL}$ denatured sheared calf thymus DNA. The filters were washed twice at room temperature (30 min each) and two times (30 min each) at $65^{\circ} \mathrm{C}$ in $2 \times \mathrm{SSC}, 0.2 \% \mathrm{SDS}$. Autoradiograph exposures were made at $-70^{\circ} \mathrm{C}$. Blots were scanned on a Phosphorimager (Molecular Dynamics, Sunnyvale, CA) to quantitate hybridization directly. Genotypes were identified by a 2-fold increase in the Southern hybridization signal measured for homozygous transgenics, compared with heterozygous transgenics.

Northern blot analysis. Mouse tissues were snap frozen in liquid nitrogen and total RNA was isolated by the acidguanidinium method (36). Twenty $\mu \mathrm{g}$ of RNA were electrophoresed through $1 \%$ agarose gels containing $2 \%$ formaldehyde, transferred to nylon filters and fixed by UV cross-linking (Stratagene). Filters were incubated with a $\left[{ }^{32} \mathrm{P}\right] \mathrm{dCTP}$ labeled nef cDNA (35) or human S14 ribosomal protein (59246; American Type Culture Collection, Rockville, MD). Labeling was accomplished by random primer method (BoehringerMannheim). Hybridizations were carried out at $43^{\circ} \mathrm{C}$ in Hybrisol (Oncor, Gaithersburg, MD) containing 50\% formamide, and the filters were washed twice at room temperature and twice at $53^{\circ} \mathrm{C}$ in $2 \times \mathrm{SSC}, 0.2 \%$ SDS. Autoradiograph exposures were made at $-70^{\circ} \mathrm{C}$. Blots were scanned on a Phosphorimager (Molecular Dynamics) to directly quantitate the relative hybridization signals in individual bands. Results were expressed as the ratio of HIV-1 to S-14 to control for differences in gel-loading and transfer efficiency.

Embryo transfer. Embryos generated in heterozygous transgenic matings were transferred into the reproductive tract of transgenic and nontransgenic foster mothers by the method of Hogan et al. (37). Briefly, heterozygous transgenic females were superovulated by the administration of pregnant mare's serum (Sigma Chemical Co., St. Louis, MO) followed by human chorionic gonadotropin (Sigma) $48 \mathrm{~h}$ later and then mated with heterozygous transgenic males. Zygotes were obtained on the morning of the cervical copulation plug. Thirteen to 15 zygotes were surgically implanted into the oviducts of pseudopregnant transgenic and nontransgenic recipients.

Statistical analysis. Results are expressed as mean $\pm \mathrm{SD}$. Data were analyzed by one-way analysis of variance, followed by post hoc analysis using the Newman-Keuls test. $p<0.05$ was considered significant. The nonparametric Kruskal-Wallis test was used when differences in SD values between groups was significant.

\section{RESULTS}

Growth deficits are manifested postnatally in Tg26 mice. As shown in Figure 1, mice homozygous for the noninfectious HIV-1 proviral genome manifest profoundly deficient growth. To determine the onset of growth delay in transgenic mice, homozygous and heterozygous transgenics and nontransgenic controls were weighed during gestation, within $24 \mathrm{~h}$ of birth, and during the first week of postnatal development (Figs. 2 and 3).

Fetal pups were harvested at 18 to $19 \mathrm{~d}$ of gestation. The average weights of homozygous, heterozygous, and nontrans- 


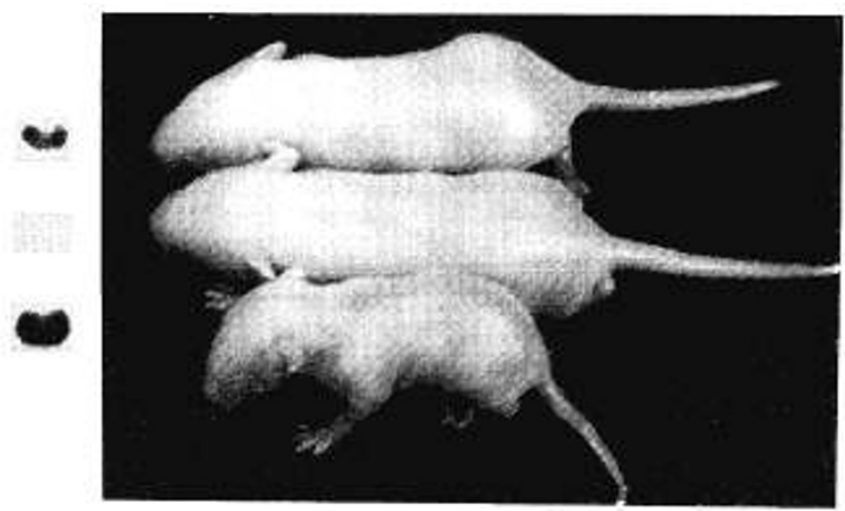

Figure 1. Normal and HIV-1 neonatal mice. At $6 \mathrm{~d}$ of age, the mouse homozygous for the HIV-1 transgene (bottom) displayed a marked reduction in growth compared with its heterozygous (top) and nontransgenic (middle) littermates. Left, Genotypes were determined by Southern hybridization of tail DNA $(10 \mathrm{mg})$ using a $\left[{ }^{32} \mathrm{P}\right]$-labeled HIV-1 nef cDNA probe, with mice homozygous for the HIV transgene displaying twice the hybridization signal as heterozygotes.
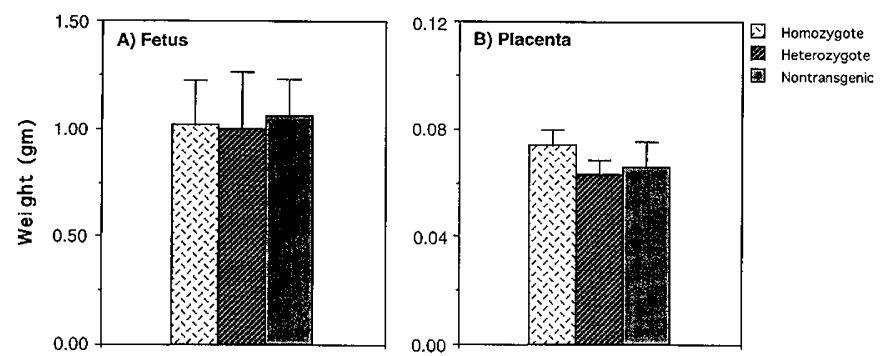

Figure 2. Intrauterine growth in HIV-transgenic mice. $A$, Fetuses generated in three heterozygous transgenic matings were harvested on d 18 or 19 of gestation and weighed. No difference in body weight was observed between homozygous $(n=7)$, heterozygous $(n=13)$, and nontransgenic $(n=7)$ fetal pups. $B$, Placentas were collected from the fetuses shown in $A$, with no significant difference in weight observed between placentas obtained from homozygous, heterozygous, and normal fetuses. The values reported are expressed as mean weight $(\mathrm{g}) \pm \mathrm{SD}$.

genic fetal pups are compared in Figure $2 A$. No difference in mean weight was observed between fetal mice bearing the HIV-1 transgene and their nontransgenic littermates. During the analysis of growth in fetal mice, we also determined the weights of the placentas. As shown in Figure $2 B$, no statistical difference in weight was detected between placentas collected from transgenic and nontransgenic fetuses.

During the first week of postnatal development, mice homozygous for the HIV-1 transgene manifested a sharply reduced growth rate that began on the first day of life (Fig. 3). Thus, within $24 \mathrm{~h}$ of birth, homozygotes were $90 \%$ of the weight of nontransgenic littermates (Fig. $3 A$ ), suggesting fluid volume loss. By $3 \mathrm{~d}$ of age, the mean weight of homozygotes had dropped to $85 \%$ of control weight (Fig. $3 B$ ), and by $6 \mathrm{~d}$ after birth, homozygotes were $73 \%$ of the weight of nontransgenic siblings (Fig. 3C). Of 14 homozygous mice followed in this study, three homozygotes became clinically cachectic and died on $\mathrm{d} 5,6$, and 7 after birth. These animals were omitted from the weight measurements made on $\mathrm{d} 3$ and 6 . Three additional homozygous transgenics died at the end of their second week of life. Homozygotes surviving past 2 wk became cachectic and died or were killed by 1 to 2 mo of age. Only

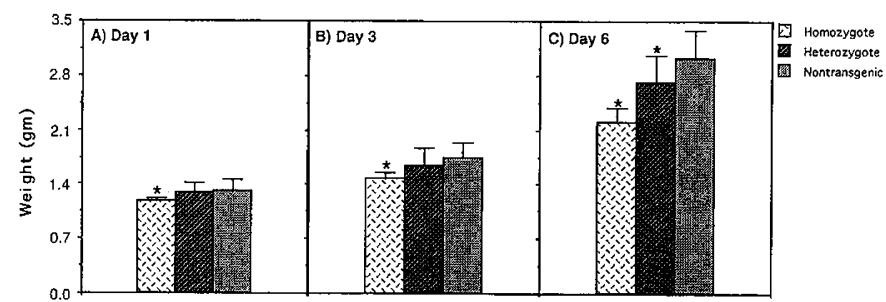

Figure 3. Postnatal growth failure in homozygous HIV-transgenic mice. Homozygous $(n=14)$, heterozygous $(n=13)$, and nontransgenic $(n=12)$ mice were weighed at the times indicated after birth. Within $24 \mathrm{~h}$ of birth $(A)$, homozygous mice displayed a reduced body weight, weighing $90 \%$ of nontransgenic controls $(p<0.035)$. By $3 \mathrm{~d}$ of age $(B)$, homozygotes were $85 \%$ of normal weight $(p<0.001)$, and by their sixth day of life $(C)$, the weight of homozygous transgenics was only $73 \%$ of nontransgenic littermates $(p<$ 0.001 ). Three homozygotes died during their first week of life and were not included in the measurements made on $\mathrm{d} 3$ and 6 . Heterozygotes had a slightly reduced growth rate during the first week of life; weights were $89 \%$ of normal littermates on $\mathrm{d} 6(p<0.057)$. Values given are expressed as mean weight (g) $\pm \mathrm{SD}$.

shortly before death did affected animals become sluggish and reduce their food intake. We killed several growth-retarded homozygous neonates during their first week of life, and at autopsy all stomach specimens were found to contain milk (not shown).

To exclude the possibilities that altered nursing behavior due to sibling competition or that deleterious effects associated with transgenic mothers contributed to growth failure, four homozygous newborns were given to nontransgenic foster mothers. No improvement in growth rate was observed among fostered neonatal mice (not shown). Finally, to determine whether nursing behavior was comparable in all mice, 2- or 4-d-old homozygous, heterozygous, and nontransgenic littermates were separated from mothers and then allowed to nurse. As shown in Figure 4, no significant difference in body weight gain after nursing was detected between fasted transgenic and nontransgenic siblings. These results indicate that growth impairment in homozygous HIV-transgenic neonates is not due to altered suckling behavior or decreased milk intake.

As shown in Figure $3 A-C$, mice heterozygous for the HIV-1 transgene tended to gain weight more slowly than their nontransgenic littermates during their first week of life. In contrast to what we observed among homozygous transgenics, the difference in mean body weight between heterozygotes and nontransgenics became statistically significant only by $6 \mathrm{~d}$ of age, at which time the weight of heterozygous pups plateaued (not shown) at about $10 \%$ below normal. All heterozygous mice thrived during the neonatal period and lived into adulthood.

Rate of pregnancy is reduced in mice transgenic for HIV-1 transgene. The previous results indicate that intrauterine growth of homozygous fetuses in transgenic mothers is equal to that of heterozygous transgenic and nontransgenic littermates. To explore the potential contribution of HIV-1 on the maternal influence of prenatal growth, 1-d-old embryos generated in heterozygous transgenic matings were transferred into normal foster mothers. Again, no significant difference in average fetal weight $(1.16 \pm 0.180 \mathrm{~g})$ was observed on $\mathrm{d} 19$ of gestation compared with the average weight $(1.17 \pm 0.032 \mathrm{~g})$ 


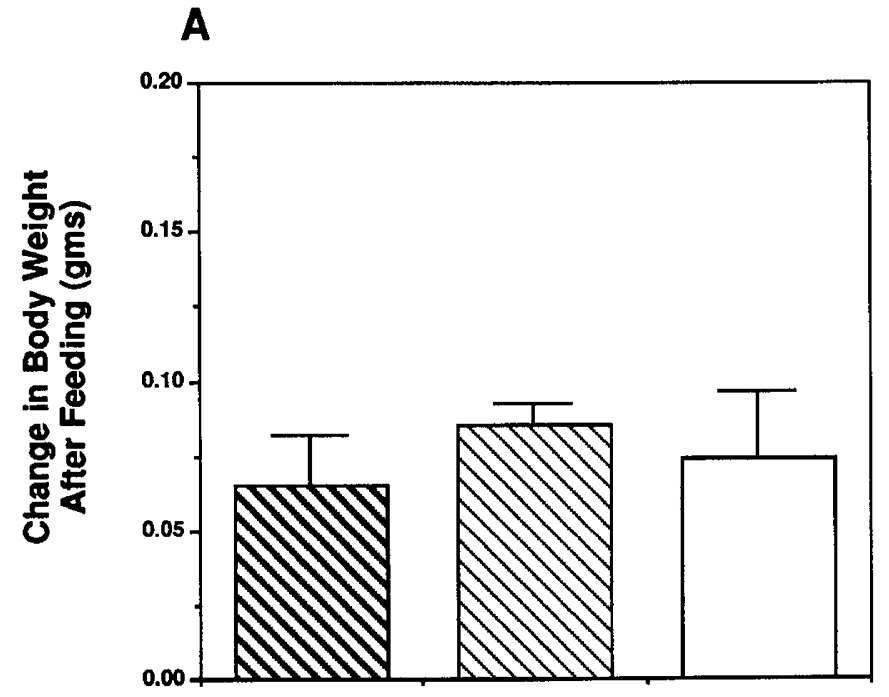

2 Days of Age
B

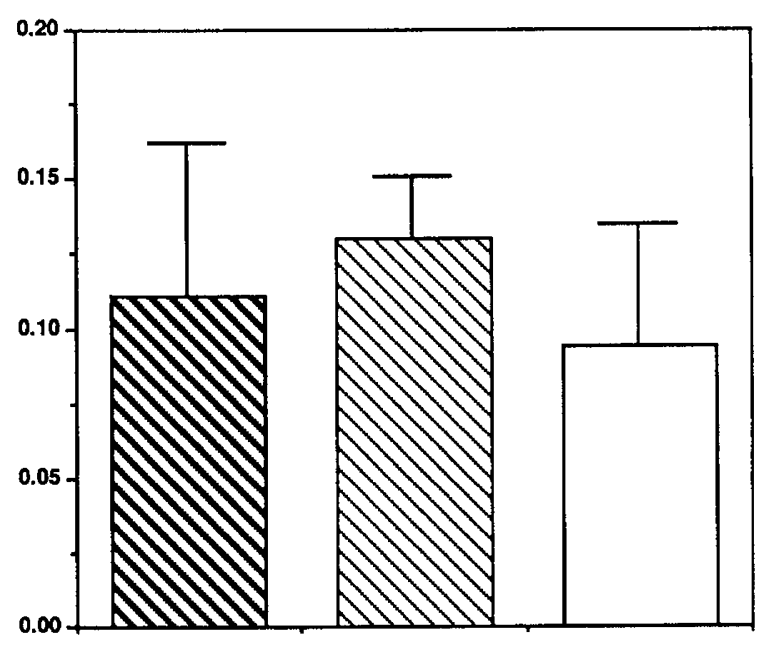

4 Days of Age

Figure 4. Milk intake in transgenic and nontransgenic nurslings. Homozygous, heterozygous, and nontransgenic neonatal mice in four litters were fasted for a period of 4.5-5.0 h and weighed. Siblings were returned to their heterozygous transgenic mothers and allowed to nurse. At the end of the feeding period, weight measurements were repeated. No significant difference in body-weight gain after nursing was observed between homozygous, heterozygous, and nontransgenic pups $(A, n=5,8$, and 4 , respectively; $B, n=3,13$, and 3, respectively). Values are expressed as mean weight gain (g) \pm SD.

of fetuses left to develop in their own transgenic mothers (results not shown). These data suggest that fetal growth is normal in mothers carrying the HIV-1 transgene.

During the course of this study, however, the pregnancy rate among HIV-transgenics was found to be remarkably low (Fig. 5). For example, in crosses with heterozygous transgenic males, only $29 \%$ of mice in a cohort of 14 heterozygous transgenic females became pregnant after successful copulation, compared with $100 \%$ among 11 age-matched nontransgenic females (Fig. 5A). A similar result was observed when embryos generated in heterozygous matings and harvested on d 1 of gestation were transferred into foster mice. Thus, in only $20 \%$ of five recipient transgenic females was pregnancy established, compared with $83 \%$ of six recipients in the nontransgenic group (Fig. 5B). This suggests that the low pregnancy rate among HIV-1 transgenic mice is due to a postfertilization defect(s) rather than a decrease in fertilization efficiency.

HIV-I genes are expressed in utero and in neonatal transgenic mice. We investigated HIV-1 gene expression in transgenic mice by Northern hybridization analysis of total RNA extracted from tissue samples (Figs. 6-8). Hybridizations were performed using a nef cDNA probe that overlaps the $3^{\prime}$ LTR and therefore detects all HIV mRNA species. In 10-d-old homozygous neonates, viral RNA species of approximately 7 , 4 , and $2 \mathrm{~kb}$ (unspliced, singly spliced, and multiply spliced transcripts, respectively) were abundantly expressed in skin, skeletal muscle, and eye (Fig. 6A). Lower amounts of viral transcripts were variably expressed in other tissues: colon, small intestine, stomach, liver, kidney, lung, brain, spinal cord, spleen, thymus, and lymph node. Not shown here, HIV mRNA was also detected in tongue in amounts that approximated those of skin and eye.

The tissue distribution of HIV-1 transcripts in homozygous and heterozygous transgenic mice was comparable (not shown). Figure $6 B$ compares the level of viral gene expression in homozygous and heterozygous neonatal skin biopsies taken from littermates at $10 \mathrm{~d}$ of age. Viral mRNA expression was greater in homozygous transgenic mouse skin (lane 1) when compared with skin from heterozygotes (lane 2). Quantitation of the blot shown in Figure $6 B$ demonstrated a 10 - to 20 -fold increase in the amount of HIV-1 gene expression in homozygous skin. Not shown, the level of HIV-1 gene expression varied between individuals and was higher in homozygous mice in some but not all tissues. These results indicate that the level of HIV-1 gene expression is not directly correlated with transgene dosage and suggest that other factors may modulate the level of expression in individual tissues.

To determine whether the HIV-1 transgene was also expressed in utero, RNA extracted from fetal skin samples and placentas harvested at $18 \mathrm{~d}$ of gestation was examined (Fig. 7). As shown in Figure $7 A$, viral mRNA was abundantly expressed prenatally, with 4- to 6-fold greater expression observed in homozygous (lane 1) fetal skin compared with skin obtained from heterozygous (lane 2) siblings; control RNA extracted from nontransgenic littermates (lane 3) was negative. Low levels of expression were demonstrated in placentas (Fig. $7 B$ ) 


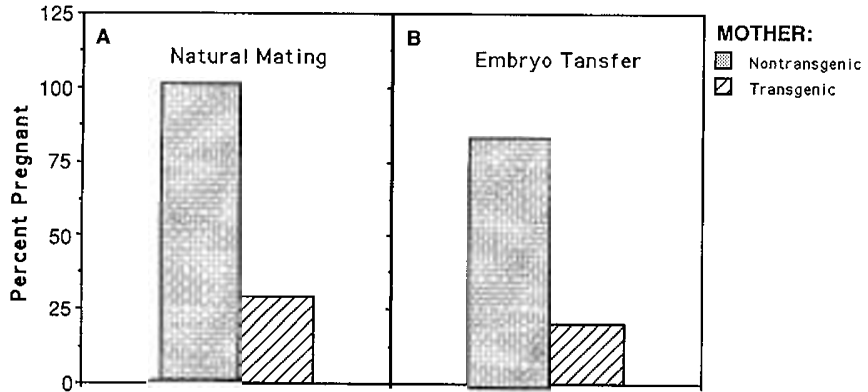

Figure 5. Reduced pregnancy rate in HIV-transgenic mice. A, Heterozygous transgenic female mice and nontransgenic age-matched controls were mated with heterozygous males. Successful copulation was verified by the presence of cervical copulation plugs the next morning. Of 14 heterozygous females, only four (29\%) were found subsequently to be pregnant, compared with 11 of $11(100 \%)$ nontransgenic females. $B$, One-cell embryos generated in crosses between superovulated heterozygous females and heterozygous males were harvested and transferred into the oviducts of pseudopregnant transgenic and nontransgenic foster mothers. Of five recipient heterozygous transgenic mice, one $(20 \%)$ became pregnant as a result of the embryo transfer, whereas five of six $(83 \%)$ recipient nontransgenic controls became pregnant.

collected from both homozygous and heterozygous transgenic fetuses (lanes 4 and 5). Although the major portion of the placenta originates from the conceptus, it does include a maternal component (decidua basalis). Inasmuch as the mothers in these experiments were heterozygous transgenics (see Methods), the expression that we observed in placental tissue could have been of fetal or maternal origin. HIV transcripts were not, however, detected in placentas derived from the nontransgenic littermates of heterozygous mothers (Fig. $7 B$, lane 6), indicating little, if any, maternal-cell contribution to transgene activity in placenta.

Transgene activity was also examined in uterine tissue. HIV mRNA was not detected in uterine tissue samples harvested from nonpregnant heterozygous transgenics (Fig. 8, lane 1). Interestingly, viral transcripts were easily detected in uterine tissue samples obtained from pregnant heterozygous mothers (Fig. 8, lane 2). These results suggest that HIV gene expression is induced by pregnancy in uterine tissue in $\mathrm{Tg} 26$ mice. When the level of expression in skin was compared between nonpregnant and pregnant mice, no significant difference was detected (Fig. 8, lanes 3 and 4), implying that the viral mRNA is not globally up-regulated by pregnancy in HIV transgenics.

\section{DISCUSSION}

Growth retardation, FTT, and cachexia are common features of vertically transmitted HIV-1 infection, although the pathophysiology is not understood. FTT may be the presenting symptom of HIV infection in young children, suggesting that growth effects are not necessarily secondary to the child's overall medical condition $(16,17)$. As the clinical and immunologic manifestations of infection progress, however, children experience increasingly profound growth retardation. Several factors implicated in the pathogenesis of poor growth or cachexia associated with HIV infection in both children and adults include endocrine dysfunction (38-40), impaired gastrointestinal function (41-43), altered cytokine production (20, $44,45)$, and excessive energy expenditure (46), as well as poor

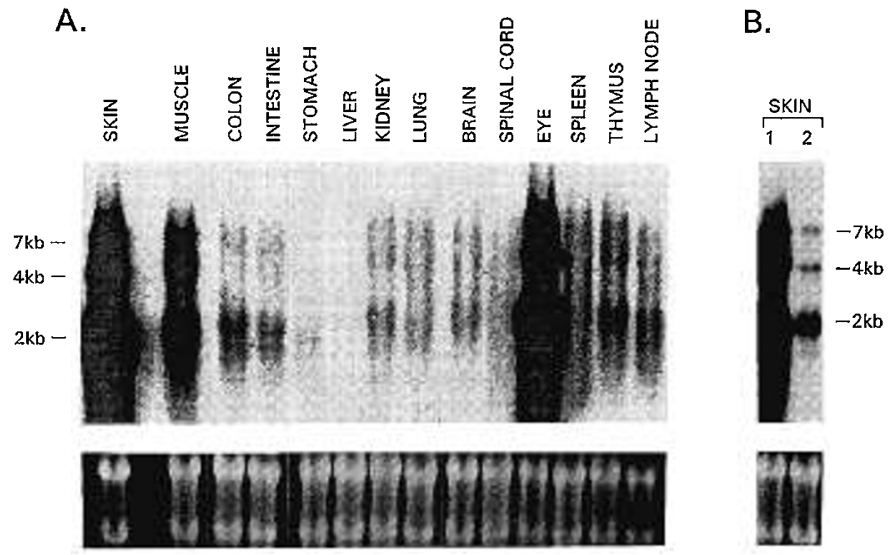

Figure 6. HIV-1 gene expression in neonatal mice. Total RNA was extracted from tissues of 10 -d-old neonates. Transgene expression was examined by Northern blot analysis using a $\left[{ }^{32} \mathrm{P}\right]$-labeled HIV nef cDNA probe. Top, hybridization with the nef probe. Bottom, ethidium bromide stain indicating relative amounts (11-25 $\mu \mathrm{g})$ of RNA loaded. A, HIV-1 transgene mRNA 7, 4, and $2 \mathrm{~kb}$ in length were abundantly expressed in homozygous transgenic skin, skeletal muscle, and eye. Lower levels of HIV-transgene expression were observed in colon, intestine, stomach, liver, kidney, lung, brain, spinal cord, and lymphoid organs (spleen, thymus, and lymph node). $B$, Expression of HIV mRNA was found to be increased 10- to 20-fold in skin from homozygous neonatal mice (lane l) compared with skin from heterozygous littermates (lane 2). The hybridized blot in $A$ was analyzed using a Phosphorimager; the hybridized blot in $B$ was analyzed by autoradiography.

oral intake. A consistent cause of growth failure has not emerged, and a multifactorial etiology seems likely. Conclusive evidence regarding congenital HIV infection and intrauterine growth is also lacking, due in part to difficulties in determining the actual timing of vertical transmission (47), to potential negative effects of maternal HIV infection on birth weight $(14,24)$, and to socially related maternal risk factors that, themselves, are correlated with low gestational weight (48).

In this report, we describe the use of a transgenic mouse model to identify potential effects of maternal, fetal, and neonatal HIV-1 gene expression on growth. Our results demonstrate that growth failure is manifested postnatally in mice expressing a nonreplicating HIV-1 genome encoding envelope and accessory gene products, with a profound reduction in growth rate observed in mice homozygous for the HIV transgene compared with heterozygous and nontransgenic pups. FTT and cachexia were manifested in homozygous transgenics, and all homozygotes died at a young age. The difference in phenotype between homozygous and heterozygous neonates is correlated with a difference in the level of expression of HIV-1 mRNA, which was shown to be higher in homozygous animals. These findings suggest that HIV-1 gene expression, independent of viral replication, is sufficient to induce neonatal growth deficits and implicate virally encoded products in the pathogenesis of growth retardation. The alternative explanation, that the disease phenotype in homozygous transgenics is due to the disruption of an essential gene as a result of transgene integration, is unlikely because an identical syndrome of growth failure, cachexia, and early death was manifested in heterozygous transgenic mice carrying copies of the infectious pNL4-3 provirus (49). 
A.

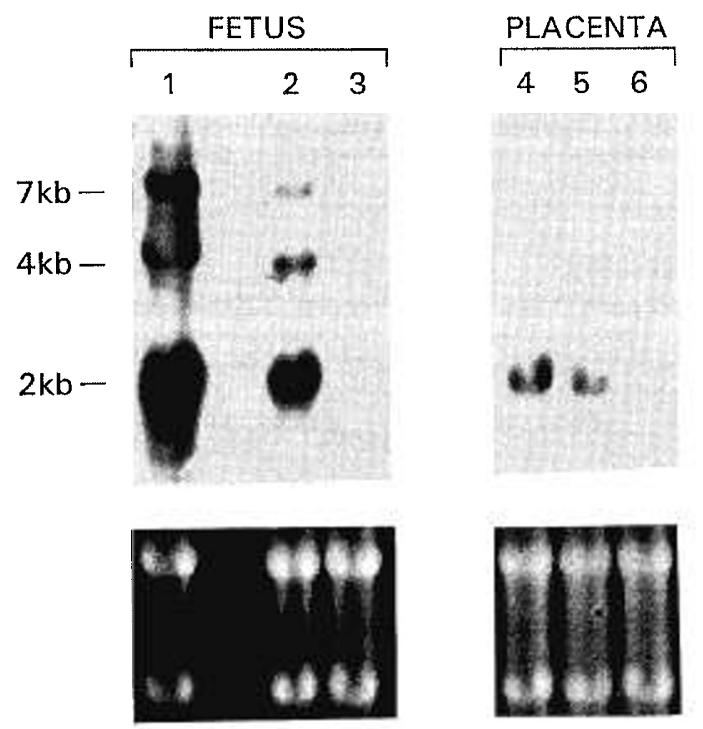

Figure 7. HIV-1 gene expression in fetal mice. Fetal pups generated in heterozygous matings were harvested on $\mathrm{d} 18$ of gestation. Total RNA $(20 \mu \mathrm{g})$ extracted from fetal skin samples $(A)$ and placentas $(B)$ was examined for HIV-transgene expression by Northern blot analysis. Top, hybridization with the HIV nef cDNA probe. Bottom, ethidium bromide stain demonstrating approximately equal loading in each lane. Lane 1, homozygous fetal skin; lane 2 , heterozygous fetal skin; lane 3, nontransgenic fetal skin; lane 4, homozygous placental tissue; lane 5, heterozygous placental tissue; and lane 6, nontransgenic placental tissue. Viral mRNA were highly expressed in transgenic fetal skin, with an approximately 4-fold to 6-fold increase in the level of expression in homozygous skin, compared with heterozygous skin. Reduced levels of HIV mRNA are expressed in placentas harvested from the transgenic fetuses. Autoradiographic exposure times were $20 \mathrm{~h}(A)$ and $60 \mathrm{~h}(B)$.

In this study, the onset of growth delay in HIV transgenic mice has been found to occur during postnatal development, despite prominent viral gene expression in maternal, fetal, and placental tissues during pregnancy. Growth of the developing fetus results from a complex interplay of placental, maternal, and fetal factors, which include provision of an adequate supply of nutrients from the mother, the ability of the placenta to affect transfer of the required nutrients to the fetus, and the endocrine control of growth within the fetus. Our results suggest that these factors are unaffected, and that the intimate association between mother and fetus may protect against potentially adverse effects of viral gene expression. Alternatively, the level of HIV-transgene activity in the developing fetus may be too low to influence growth. In this regard, viral gene expression in homozygous transgenics is dramatically increased postnatally compared with the level of expression observed in homozygous fetal pups (compare Figs. $6 B$ and $7 B$ ). Whether this is due to suppression in utero of viral gene expression by a maternal or fetal factor(s) or to transactivation of the HIV-1 transgene postnatally is not known.

At birth, fetal dependence on mother and placenta is abruptly halted and the achievement of further growth requires activation and functional interaction between the different organ systems, as well as a continuing supply of exogenous nutrients. The growth retardation in neonatal transgenics may be due to several factors acting alone or in combination. For example, homozygous transgenic mice display abundant viral

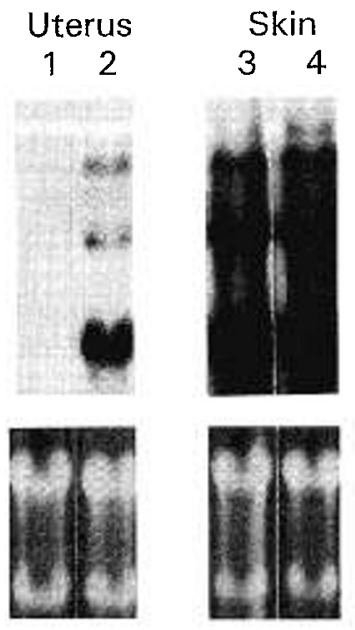

Figure 8. Induction of HIV-1 gene expression in uterine tissue during pregnancy. Total RNA was extracted from uterine tissue (left) and skin samples (right) obtained from heterozygous transgenic mice. Northern blot analysis was performed with $20 \mu \mathrm{g}$ of RNA. Top, hybridization with the nef probe. Bottom, ethidium bromide stain. Lane $I$, uterine tissue from a nonpregnant transgenic mouse; lane 2, uterine tissue from an age-matched transgenic mouse on d 15 of pregnancy; lane 3, skin from the nonpregnant transgenic mouse shown in lane 1; and lane 4, skin from the pregnant transgenic mouse shown in lane 2. Expression of the HIV-1 genome is induced in uterine tissue during pregnancy in heterozygous transgenic mice (compare lanes 1 and 2). In contrast, there is no significant difference in the level of expression in transgenic skin between the nonpregnant and pregnant mice (compare lanes 3 and 4). Embryos and placentas were expelled from the pregnant uterus before RNA extraction. Autoradiographic exposure times were $60 \mathrm{~h}$ (uterus) and 30 h (skin).

gene expression in tongue and gastrointestinal tract, which raises the possibility of altered taste or suckling reflex, resulting in reduced food intake, or impaired food absorption. It is unlikely, however, that at least the onset of growth delay is an effect of reduced oral intake, because normal nursing was observed during the first several days of life and no significant difference in milk intake was measured when homozygotes, heterozygotes, and nontransgenic littermates were compared. Although we saw no evidence of fat malabsorptive diarrhea among homozygous mice, we cannot exclude the possibility that gastrointestinal malabsorption of protein or carbohydrate may be responsible for impaired growth. Nor can we exclude differences in renal metabolism of salt and water, particularly in view of the $10 \%$ reduction in weight in the first $24 \mathrm{~h}$. Another possibility is that growth failure in mice homozygous for the transgene relates to abundant expression of viral gene products in skin. In this regard, homozygous neonatal mice uniformly develop a progressive, and potentially debilitating, skin disease characterized clinically by dry, thickened, scaling lesions and histologically by epidermal hyperproliferation and hyperkeratosis (34). Growth-retarded mice transgenic for the infectious HIV-1 provirus were also reported to manifest this phenotype (49). Interestingly, a similar syndrome was described in transgenic mice overexpressing transforming growth factor- $\alpha$ in epidermis (50), which suggests the possibility that increased production of this or other cytokines in HIVtransgenic mouse skin may negatively influence growth. Skin may also represent a significant site of free water loss. Alter- 
natively, expression of even relatively small amounts of HIV proteins in any of the number of tissues that activate the viral transgene may dysregulate the production or secretion of cellular factors, e.g. cytokines and growth factors, or the ability of target tissues to respond to such factors, that are required for continued growth outside the uterine environment.

Our observations related to HIV-1 transgene activity during pregnancy raise several interesting issues. First, viral gene expression was found to be induced by pregnancy in uterine tissue in $\operatorname{Tg} 26$ mice. This observation is consistent with the result of Furth et al. (51), who demonstrated increased HIV LTR-directed reporter gene activity in uterine tissue during pregnancy in another transgenic line and suggested that this up-regulation may be due to a stimulatory effect of steroid hormones on the LTR (viral promoter). Steroids are known to increase transcription of several retroviruses via interaction of their respective receptors with specific sequences termed glucocorticoid response elements (52-54). Several potential glucocorticoid response elements have been identified throughout the HIV-1 genome (55-58), and recent reports suggest that at least two of these sequences can respond directly to glucocorticoid induction in vitro $(55,58)$. Although none of these observations constitute direct evidence for steroid stimulation of the HIV-1 genome in vivo, our finding that the viral genome is induced by pregnancy is consistent with a role for steroids in modulating HIV transcription.

Second, in this study, HIV-1 gene expression in transgenic animals was associated with a remarkably low pregnancy rate. Our embryo transfer experiments imply that this reduction is due to a postfertilization defect. These observations raise the possibility that HIV-derived or HIV-induced factors could interfere with blastocyst implantation or decidua formation. Whether this effect is related to the viral gene expression that we observed in uterine tissue of transgenic mothers, to potential systemic effects of maternal HIV gene expression, or to viral gene activity in the developing embryo is not known. It has recently been reported that HIV infection of human placental explants in vitro decreases progesterone and human chorionic gonadotropin production (59). From our data, it is tempting to speculate that viral gene activity in HIV-transgenic mice may negatively influence the normal production of such hormones, which are required to support the developing conceptus and maintain the pregnancy. In humans, however, the overall pregnancy rate in HIV-infected women does not appear to be reduced (23).

In summary, expression of an HIV-1 proviral construct encoding envelope and regulatory genes in transgenic mice was associated with postnatal growth failure and cachexia. No effect of maternal and fetal transgene expression on prenatal growth was observed, suggesting that the mother may confer protection from growth effects and that postnatal events are responsible for the observed impairment in growth. Our data suggest that HIV-transgenic mice provide an important in vivo model for investigating the viral gene products involved and the pathogenic mechanisms leading to growth inhibition in HIV-infected children. The application of these findings to humans remains to be determined.

\section{REFERENCES}

1. Sprecher S, Soumenkoff G, Puissant F, Degueldre M 1986 Vertical transmission of HIV in 15-week fetus. [letter] Lancet 2:288-289

2. Jovaisas E, Koch MA, Schäfer A, Stauber M, LÖwenthal D 1985 LAV/HTLV-III in 20-week fetus. [letter] Lancet 2:1129

3. Lewis SH, Reynolds-Kohler C, Fox HE, Nelson JA 1990 HIV-1 in trophoblastic and villous Hofbauer cells, and haematological precursors in eight-week fetuses. Lancet $1: 565-568$

4. Luzuriaga K, McQuilken P, Alimenti A, Somasundaran M, Hesselton R, Sullivan JL 1993 Early viremia and immune responses in vertical human immunodeficiency virus type 1 infection. J Infect Dis 167:1008-1013

5. Rudin C, Meier D, Pavic N, Nars PW, Berger R, Ohnacker H, Probst A, Erb P 1993 Intrauterine onset of symptomatic human immunodeficiency virus disease. The Swiss Collaborative Study Group "HIV and Pregnancy." Pediatr Infect Dis J 12:411--414

6. Goedert JJ, Duliëge AM, Amos CI, Felton S, Biggar RJ 1991 High risk of HIV-1 infection for first-born twins. The International Registry of HIV-Exposed Twins. Lancet 1:1471-1475

7. Ehrnst A, Lindgren S, Dictor M, Johansson B, SÖnnerborg A, Czajkowski J, Sundin $\mathrm{G}$, Bohlin $\mathrm{AB} 1991 \mathrm{HIV}$ in pregnant women and their offspring: evidence for late transmission. Lancet 1:203-207

8. Krivine A, Firtion G, Cao L, Francoual C, Henrion R, Lebon P 1992 HIV replication during the first weeks of life. Lancet 1:1187-1189

9. Senturia YD, Peckham CS 1987 HIV infection in children: sizing up the paediatric problem. Paediatr Perinat Epidemiol 1:143-151

10. Colebunders R, Kapita B, Nekwei W, Bahwe Y, Lebughe I, Oxtoby M, Ryder R 1988 Breastfeeding and transmission of HIV. [letter] Lancet 2:1487

11. Stiehm ER, Vink P 1991 Transmission of human immunodeficiency virus infection by breast-feeding. J Pediatr 118:410-412

12. Van de Perre P, Hitimana DG, Simonon A, Dabis F, Msellati P, Karita P, Lepage P 1992 Postnatal transmission of HIV-1 associated with breast abscess. [letter] Lancet 339:1490-1491

13. Courgnaud V, Laurë F, Brossard A, Bignozzi C, Goudeau A, Barin F, Brëchot C 1991 Frequent and early in utero HIV-1 infection. AIDS Res Hum Retroviruses 7:337-341

14. Gabiano C, Tovo PA, de Martino M, Galli L, Giaquinto C, Loy A, Schoeller MC Giovannini M, Ferranti G, Rancilio L 1992 Mother-to-child transmission of human immunodeficiency virus type 1: risk of infection and correlates of transmission. Pediatrics 90:369-374

15. Borkowsky W, Krasinski K 1992 Perinatal human immunodeficiency virus infection ruminations on mechanisms of transmission and methods of intervention. Pediatrics 90:133-136

16. Rubinstein A 1986 Pediatric AIDS. In: Current Problems in Pediatrics, 16th Ed. Year Book Medical Publishers, Chicago, pp 362-409

17. Jason J, Gomperts E, Lawrence DN, Holman RC, Bouhasin JD, Miller R, Evatt BL 1989 HIV and hemophilic children's growth. J Acquired Immune Defic Syndr 2:277-282

18. Johnson JP, Nair P, Hines SE, Seiden SW, Alger L, Revie DR, O'Neil KM, Hebel R 1989 Natural history and serologic diagnosis of infants born to human immunodeficiency virus-infected women. Am J Dis Child 143:1147-1153

19. Pizzo PA 1990 Pediatric AIDS: problems within problems. J Infect Dis 161:316-325

20. Arditi M, Kabat W, Yogev R 1991 Serum tumor necrosis factor alpha, interleukin 1-beta, p24 antigen concentrations and CD4+ cells at various stages of human immunodeficiency virus 1 infection in children. Pediatr Infect Dis J 10:450-455

21. Connor E 1993 Pediatric HIV infection: what can you do. J Respir Dis 14:75-90

22. Ryder RW, Nsa W, Hassig SE, Behets F, Rayfield M, Ekungola B, Nelson AM, Mulenda U, Francis H, Mwandagalirwa K 1989 Perinatal transmission of the human immunodeficiency virus type 1 to infants of seropositive women in Zaire. N Engl J Med 320:1637-1642

23. Selwyn PA, Schoenbaum EE, Davenny K, Robertson VJ, Feingold AR, Shulman JF Mayers MM, Klein RS, Friedland GH, Rogers MF 1989 Prospective study of human immunodeficiency virus infection and pregnancy outcomes in intravenous drug users. JAMA 261:1289-1294

24. Halsey NA, Boulos R, Holt E, Ruff A, Brutus JR, Kissinger P, Quinn TC, Coberly JS Adrien M, Boulos C 1990 Transmission of HIV-1 infections from mothers to infants in Haiti. Impact on childhood mortality and malnutrition. The CDS/JHU AIDS Project Team. JAMA 264:2088-2092

25. Lepage P, Dabis F, Hitimana DG, Msellati P, Van Goethem C, Stevens AM Nsengumuremyi F, Bazubagira A, Serufilira A, De Clercq A 1991 Perinatal transmission of HIV-1: lack of impact of maternal HIV infection on characteristics of livebirths and on neonatal mortality in Kigali, Rwanda. AIDS 5:295-300

26. Hand IL, Wiznia A, Checola RT, Kim MH, Noble LM, Daley TJ, Yoon JJ 1992 Human immunodeficiency virus seropositivity in critically ill neonates in the south Bronx. Pediatr Infect Dis J 11:39-42

27. Miller TL, Evans SJ, Orav EJ, Morris V, McIntosh K, Winter HS 1993 Growth and body composition in children infected with the human immunodeficiency virus-1. Am J Clin Nutr 57:588-592

28. Geffner ME, Vandop C, Landaw EM, Yeh DY, Stiehm ER, Bryson YJ, Brunnel PA 1992 Growth-patterns of children born to mothers infected with human immunodeficiency virus-1 (HIV-1). Clin Res 40:132(abstr)

29. Rossi P, Moschese V 1991 Mother-to-child transmission of human immunodeficiency virus. FASEB J 5:2419-2426

30. Backë E, Unger M, Jimenez E, Siegel G, Schäfer A, Vogel M 1993 Fetal organs infected by HIV-1. [letter] AIDS 7:896-897

31. Dickie P, Felser J, Eckhaus M, Bryant J, Silver J, Marinos N, Notkins AL 1991 HIV-associated nephropathy in transgenic mice expressing HIV-1 genes. Virology 185:109-119 
32. Santoro TJ, Bryant JL, Pellicoro J, Klotman ME, Kopp JB, Bruggeman LA, Franks RR, Notkins AL, Klotman PE 1994 Growth failure and AIDS-like cachexia syndrome in HIV-1 transgenic mice. Virology 201:147-151

33. Kopp JB, Klotman ME, Adler SH, Bruggeman LA, Eckhaus M, Dickie P, Marinos NJ, Bryant JL, Notkins AL, Klotman PE 1992 Progressive glomerulosclerosis and enhanced renal accumulation of basement membrane components in mice transgenic for HIV-1 genes. Proc Natl Acad Sci USA 89:1577-1581

34. Kopp JB, Rooney JF, Wohlenberg C, Dorfman N, Marinos NJ, Bryant JL, Katz SI, Notkins AL, Klotman PE 1993 Cutaneous disorders and viral gene expression in HIV-1 transgenic mice. AIDS Res Hum Retroviruses 9:267-275

35. Ahmad N, Venkatesan S 1988 Nef protein of HIV-1 is a transcriptional repressor of HIV-1 LTR. Science 241:1481-1485

36. Chomczynski P, Sacchi N 1987 Single-step method of RNA isolation by acid guanidinium thiocyanate-phenol-chloroform extraction. Anal Biochem 162:156-159

37. Hogan B, Costantini F, Lacy E 1986 Manipulating the Mouse Embryo. A Laboratory Manual. Cold Spring Harbor Laboratory, Cold Spring Harbor, NY

38. Laue L, Pizzo PA, Butler K, Cutler Jr GB 1990 Growth and neuroendocrine dysfunction in children with acquired immunodeficiency syndrome. J Pediatr 117:541-545

39. Schwartz LJ, St Louis Y, Wu R, Wiznia A, Rubinstein A, Saenger P 1991 Endocrine function in children with human immunodeficiency virus infection. Am J Dis Child 145:330-333

40. Geffner ME, Yeh DY, Landaw EM, Scott ML, Stiehm ER, Bryson YJ, Israele V 1993 In vitro insulin-like growth factor-I, growth hormone, and insulin resistance occurs in symptomatic human immunodeficiency virus-1-infected children. Pediatr Res 34:66-72

41. Guarino A, Tarallo L, Guandalini S, Troncone R, Albano F, Rubino A 1991 Impaired intestinal function in symptomatic HIV infection. J Pediatr Gastroenterol Nutr 12:453-458

42. Miller TL, Orav EJ, Martin SR, Cooper ER, McIntosh K, Winter HS 1991 Malnutrition and carbohydrate malabsorption in children with vertically transmitted human immunodeficiency virus 1 infection. Gastroenterology 100:1296-1302

43. Yolken RH, Hart W, Oung I, Shiff C, Greenson J, Perman JA 1991 Gastrointestinal dysfunction and disaccharide intolerance in children infected with human immunodeficiency virus. J Pediatr 118:359-363

44. Rautonen J, Rautonen N, Martin NL, Philip R, Wara DW 1991 Serum interleukin-6 concentrations are elevated and associated with elevated tumor necrosis factor-alpha and immunoglobulin $\mathrm{G}$ and $\mathrm{A}$ concentrations in children with HIV infection. AIDS 5:1319-1325

45. Ellaurie M, Rubinstein A 1992 Tumor necrosis factor-alpha in pediatric HIV-1 infection. AIDS 6:1265-1268
46. Kotler DP 1990 Protein-energy malnutrition in AIDS. [editorial] Nutr Clin Pract $5: 41-42$

47. Bryson YJ, Luzuriaga K, Sullivan JL, Wara DW 1992 Proposed definitions for in utero versus intrapartum transmission of HIV-1. [letter] N Engl J Med 327:1246 1247

48. Teberg AJ, Settlage R, Hodgman JE, King Y, Aguilar T 1989 Maternal factors associated with delivery of infants with birthweight less than 2000 grams in a low socioeconomic population. J Perinatol 9:291-295

49. Leonard JM, Abramczuk JW, Pezen DS, Rutledge R, Belcher JH, Hakim F, Sheare G, Lamperth L, Travis W, Fredrickson T, Notkins AL, Martin M 1988 Development of disease and virus recovery in transgenic mice containing HIV proviral DNA. Science 242:1665-1670

50. Vassar R, Fuchs E 1991 Transgenic mice provide new insights into the role of TGF-alpha during epidermal development and differentiation. Genes Dev 5:714-727

51. Furth PA, Westphal H, Hennighausen L 1990 Expression from the HIV-LTR is stimulated by glucocorticoids and pregnancy. AIDS Res Hum Retroviruses 6:553560

52. Payvar F, DeFranco D, Firestone GL, Edgar B, Wrange O, Okret S, Gustafsson JA Yamamoto KR 1983 Sequence-specific binding of glucocorticoid receptor to MTV DNA at sites within and upstream of the transcribed region. Cell 35:381-392

53. Celander D, Haseltine WA 1987 Glucocorticoid regulation of murine leukemia virus transcription elements is specified by determinants within the viral enhancer region. J Virol 61:269-275

54. Chalepakis G, Arnemann J, Slater E, Br:uller HJ, Gross B, Beato M 1988 Differentia gene activation by glucocorticoids and progestins through the hormone regulatory element of mouse mammary tumor virus. Cell 53:371-382

55. Kolesnitchenko V, Snart RS 1992 Regulatory elements in the human immunodeficiency virus type 1 long terminal repeat LTR (HIV-1) responsive to steroid hormone stimulation. AIDS Res Hum Retroviruses 8:1977-1980

56. Ratner L, Haseltine W, Patarca R, Livak KJ, Starcich B, Josephs SF, Doran ER Rafalski JA, Whitehorn EA, Baumeister K, Ivanoff L, Petteway Jr SR, Pearson ML Lautenberger JA, Papas TS, Ghrayeb J, Chang NT, Gallo RC, Wong Staal F 1985 Complete nucleotide sequence of the AIDS virus, HTLV-III. Nature 313:277-284

57. Ghosh D 1992 Glucocorticoid receptor-binding site in the human immunodeficiency virus long terminal repeat. J Virol 66:586-590

58. Soudeyns H, Geleziunas R, Shyamala G, Hiscott J, Wainberg MA 1993 Identification of a novel glucocorticoid response element within the genome of the human immunodeficiency virus type 1 . Virology 194:758-768

59. Amirhessami-Aghili N, Spector SA 1991 Human immunodeficiency virus type 1 infection of human placenta: potential route for fetal infection. J Virol 65:2231-2236 